\title{
Sustainable Postural Research for Women Workers From Power-Loom Industry Solapur City, Maharashtra, India.
}

\author{
Somnath Kolgiri, Rahul Hiremath
}

\begin{abstract}
The majority of women workers were performing spinning, warping and finishing tasks in the power-loom industry; espousing an awkward posture. Work-related musculoskeletal disorders (WRMSDs) are most important problems related to the cyclic and challenging working awkward posture. This study focuses on identification of ergonomic physical risk factors caused because of awkward posture and explores its association with the prevalence of WRMSDs among the ladies staff from power-loom industry Solapur town, geographic area, India. The WRMSDs indications were known estimated and analyzed victimization the Nordic Musculoskeletal Questionnaire (NMQ) and Rapid Upper Limb Assessment (RULA). Statistical analysis of ANOVA was performed to search out significance between variables of anthropometry and job details to the departments. NMQ results disclosed that the very best rates of disorders were found within the upper Arm (60\%) wrist (52\%), neck (42\%), and Trunk (64\%) severally, and therefore the consequences of the RULA technique showed that the upmost level of risk within the region of upper Arm (risk level four) and within the Trunk (risk level three point five). In addition, the multivariate analysis proven that age and job expertise had a major correlation with the prevalence of MSDs (Table 1, if $P<0.05$, significant). By trying the values of correlation coefficients, there's no huge distinction to perform video analysis for analysis of RULA or NMQ for locating pain in body regions.
\end{abstract}

Keywords : Awkward Posture, NMQ, Power-loom Industry, RULA, Sustainable Analysis, WRMSDs, Women Worker.

\section{INTRODUCTION}

Curved and crouching postures are acquainted in developing countries like the Republic of India, particularly in tiny scale industries [1]. The small-scale textile employees hardly get pleasure from occupational health and safety provisions [2]. Numerous studies recommend that employees in textile business suffer from WRMSDs like forearm redness, pistil tunnel syndrome, bicapital redness, epicondilitis, lower back pain, shoulder pain, neck pain and degenerative joint disease of the knee [3]. In tiny scale textile industries standing work posture is maintained throughout the shift in operational looms together time. When raw material is wrapped, the employees push and move iron beam deliberation sevnteefive to a hundred metric weight units for a space an area of concerning 2 meters and this fabric handling is performed six to seven times per day. The duty demands high attention in observation that the threads don't break off [4]. Most of the

\footnotetext{
Revised Manuscript Received on September 10, 2019.

Somnath Kolgiri, Assistant Professor, SBPCOE, Indapur, Pune, Maharashtra, India.

(E-mail: patelnirzari84@gmail.com)

Rahul Hiremath, Assistant Professor, SCMHRD, SIU Pune, Maharashtra, India

(E-mail: m.p.barot@gmail.com)
}

physically invigorated activities in these industries are connected in awkward postures.

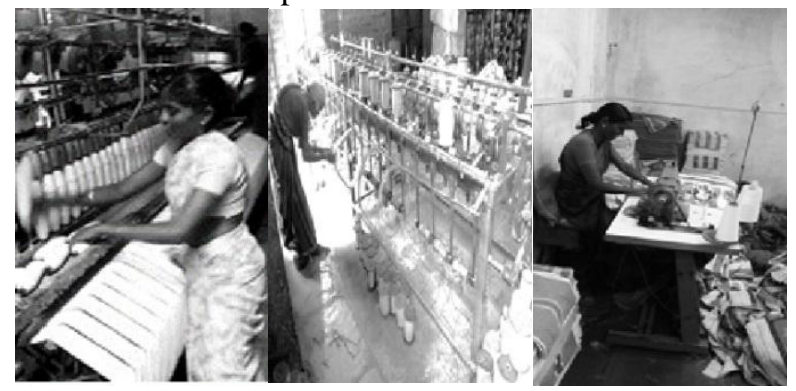

Fig.1: working posture adopted in order to perform tasks in power-loom industry.

Various investigations have established that operating conditions, and exposure to the danger of work-related injuries and sickness, have a bearing on health [5, 6]. Most prevailing health issues caused by add the trendy job market that typically attacked associate industrial employee was WMSDs [7].

System disorder (MSDs) could occur owing to incessantly playacting repetitive tasks, functioning on continual and sustained or tough postures, activity strenuous physical work, and victimization forceful exertion [8]. MSDs in the workplace are studied extensively and it's a standard notion that the work itself could be a major reason behind MSDs [9]. MSDS refers to health things that of the locomotors' equipment, i.e. Muscles, Tendons, Skeleton, Cartilage, system, Ligaments and Nerves, with back pain/injuries and work-related upper limb disorders because the core teams [10].

Work surroundings contributed to those types of disorders and are created worse by the operating conditions or workplace risk factors. WMSDs are too by origin lost work time or absence, increase work restriction, transfer to a different job, or incapacity than the other cluster of diseases with a substantial monetary charge on the individual, the organization and therefore, the society as a whole[11, 12]. As per the International Engineering Science Association (IEA, 2016), ergonomists place in to the design and gauge of undertakings, occupations, items, situations, and frameworks to make them good with the needs, abilities, and restrictions of people[13].

Applied science, assessment of WRMSDs involves the analysis of risk of developing different disorders of muscles, nerves and joints, primarily of the upper limb and low back, related to activity tasks. Several ergonomic risk assessment tools and techniques are developed and are ordinarily utilized by.ergonomists to assess exposure to renowned risk 
factors and to develop programs to prevent/reduce WRMSDs.

These techniques may be classified in three groups: selfreport, experimental techniques and direct measurements [14]. Self-reports include representative journals, meetings and surveys, despite their simple implementation, selfreports are related to subjective drawbacks just like the undependableness of revelation awareness or interpretation per the workers' accomplishment, although experimental technique's square measure reasonable and sensible to be used in an exceedingly wide selection of skillful things, the rating system could undergo from a scarcity of epidemiologic data [15].

The intent of observational techniques is to pass judgment on work environment introduction by checking on the worker's motor behavior conduct on paper sheets either though perceptive inside the field or replaying recordings [16]. Observational techniques embrace be dead into videotaped specific software's though this method is timeconsuming [17]. A lot of merely, videotaping could be a commonplace device in ergonomics because it consents to split a job sequence in many key parts, indicated as subtasks [18].

The quantity of your time spent throughout every of those subtasks may be assumed as a proportion of the job sequence. One amongst the foremost cited observational ways are the RULA index that relies on postures study (biomechanical and bodily property load constraints) to present achieve of revelation to MSDs, through scrupulous attention to the neck, trunk and upper limbs [19]. The consistency of this technique tailored to explicit settings has been evaluated through totally various investigations [20]. In this investigation, the ergonomic apparatuses won't to build up occupational risks on the staff are NMQ and RULA. The choices of the RULA were supported the tasks doing by the staff that are awkward, repetitive work and involve the whole body elements. The majority of ladies staff were activity spinning, warping and finishing tasks within the power-loom industry; espousing an ungainly posture. WRMSDs are most significant issues associated with the cyclic and difficult operating uncomfortable posture.The objective of present study is to investigate the operating postures and conduct ergonomic analysis of the works task to spot the high risk cluster for various body regions intervention with RULA, and NMQ to analyze the magnitude of musculoskeletal disorders among ladies employee of power-loom industries from Solapur city, Maharashtra, India.

\section{MATERIALS \& METHODS}

A field investigation had been carried out to gather the anthropometric and demographic knowledge of one hundred feminine employee age starting from eighteen to sixty years (Age=32.24 \pm 4.03 ) were chosen. RULA systems were wont to evaluate the posture, strength, and movement of neckline, higher \& minor back, trunk, shoulders connected to powerloom industry tasks and to evaluate the body position, forces used movement or exploit, recurrence, and coupling severally and NMQ were wont to measure the magnitude and analyze the chance of WRMSDs among power-loom business lady's staff. The statistical investigation of retort information is investigated using the SPSS package.

\section{RESULTS AND DISCUSSION}

\section{A. Field Survey}

The current workstation has been contemplated. All operators were lady's operators and accustomed do their work in a nonstop way for eight to ten hours out of each day with a rest interruption of fifteen to half-hours. Plant outline provides inadequate gaps between the workstations that cause insufficient space for reposeful legs whereas set up the equipment. Unsuitable exposure to air and be deficient in illumination intensity (325 lux) provides poor operating surroundings.

\section{B. Socio-Demographic Characteristics of Study Subjects}

Table 1 shows entire of 100 feminine subjects were deliberated. There be $32.24 \pm 4$.03years mean age; 152.26 $\pm 2.69 \mathrm{~cm}$ mean height and mean weight being $52.2 \pm 5.48 \mathrm{~kg}$. The mean work experience was $11.4 \pm 2.4$ years. On a normal, they worked for $10.0 \pm 2.8$ hours consistently.

From table 1 it depicts anthropometry metrics and job association details of workers belong to various departments in power loom industry. Statistical investigation of ANOVA was carrying out to locate significance among variables of anthropometry and job details to the departments following inferences were observed from $\mathrm{P}$ Value of Table 1. If $\mathrm{P}<$ 0.05 , it is significant

- $\quad$ Age of workers was significantly associated to the departments they belong

- Height of the female was significantly associated to the departments they belong

- Weight of the Male was significantly associated to the departments they belong

- Average years of experience was significantly associated to the departments they belong

\section{RULA analysis}

RULA is created to be utilized in ergonomic examinations of working environments wherever business related upper appendage issues is accounted for and that survey biomechanical and postural stacking on the entire body with explicit thoughtfulness for the neck, trunk, and higher appendage [21]. Table 2 shows the ultimate impressive gain for the task 1 was seven that indicate an associate action level four consideration i.e., instant examination and alterations are needed in gettable workplace. For assignment 2, the impressive score was establish to be five that suggest associate action level three i.e., timely analysis and alterations are needed in an existing workplace.

\section{NMQ Analysis}

A NMQ was used for the evaluation of labor for calculating physical uneasiness. NMQ may be a consistent screening and surveillance tool to seek out the body regions full of system symptoms comparatively inexpensive. There's 
no would like of every scientific instrumentality to demeanor this study [22].
Answers were gathered from the laborers and numerical investigation was done utilizing SPSS software packages.

Table- I: Socio-demographic characteristics of study subjects.

\begin{tabular}{|l|l|l|l|}
\hline Variable & Mean & SD & Range \\
\hline Age $($ Yr) & $32.24 \pm 4.03$ & 2.05 & $18-60$ \\
\hline Height $(\mathrm{cm})$ & $152.26 \pm 2.69$ & 2.78 & $145-165$ \\
\hline Weight $(\mathrm{kg})$ & $52.2 \pm 5.48$ & 1.03 & $45-60$ \\
\hline Work Experience (Yr) & $11.4 \pm 2.4$ & 4.07 & $1-18$ \\
\hline Weekly Working Hours & $52.5 \pm 00$ & 4.76 & $45-60$ \\
\hline
\end{tabular}

Table- II: Final scores of RULA.

\begin{tabular}{|l|l|l|l|l|l|l|l|l|l|l|l|l|l|}
\hline $\begin{array}{l}\text { Sr. } \\
\text { No. }\end{array}$ & $\begin{array}{l}\text { Dept/Body } \\
\text { Parts }\end{array}$ & $\begin{array}{l}\text { Upper } \\
\text { Arm }\end{array}$ & $\begin{array}{l}\text { Lower } \\
\text { Arm }\end{array}$ & Wrist & $\begin{array}{l}\text { Wrist } \\
\text { Twist }\end{array}$ & $\begin{array}{l}\text { Wrist/ } \\
\text { Arm } \\
\text { Posture }\end{array}$ & $\begin{array}{l}\text { Wrist// } \\
\text { Arm } \\
\text { Muscle }\end{array}$ & Neck & Trunk & Leg & $\begin{array}{l}\text { Trunk } \\
\text { Posture }\end{array}$ & $\begin{array}{l}\text { Trunk } \\
\text { Muscle }\end{array}$ & $\begin{array}{l}\text { Trunk } \\
\text { Load }\end{array}$ \\
\hline 1 & $\begin{array}{l}\text { Guiding in } \\
\text { spinning }\end{array}$ & 5 & 1 & 4 & 1 & 5 & 0 & 4 & 4 & 2 & 7 & 0 & 0 \\
\hline 2 & $\begin{array}{l}\text { Loading in } \\
\text { spinning }\end{array}$ & 3 & 3 & 4 & 1 & 7 & 0 & 2 & 3 & 2 & 5 & 1 & 0 \\
\hline 3 & $\begin{array}{l}\text { Guiding in } \\
\text { Warping }\end{array}$ & 4 & 2 & 4 & 1 & 5 & 1 & 3 & 4 & 2 & 6 & 0 & 0 \\
\hline 4 & $\begin{array}{l}\text { Warping } \\
\text { from spool }\end{array}$ & 4 & 3 & 3 & 1 & 5 & 1 & 3 & 2 & 2 & 4 & 0 & 0 \\
\hline 5 & $\begin{array}{l}\text { Warping } \\
\text { Thread }\end{array}$ & 6 & 3 & 3 & 1 & 9 & 1 & 3 & 3 & 2 & 5 & 0 & 0 \\
\hline 6 & $\begin{array}{l}\text { Beam } \\
\text { Threading }\end{array}$ & 4 & 3 & 3 & 1 & 5 & 1 & 3 & 4 & 2 & 6 & 1 & 0 \\
\hline 7 & Removal & 3 & 3 & 3 & 1 & 4 & 1 & 3 & 4 & 2 & 5 & 1 & 0 \\
\hline 8 & Sewing & 3 & 2 & 3 & 1 & 4 & 1 & 3 & 4 & 2 & 6 & 1 & 0 \\
\hline 9 & $\begin{array}{l}\text { RULA } \\
\text { Total } \\
\text { Score }\end{array}$ & 41 & 24 & 35 & 10 & 56 & 6 & 29 & 35 & 20 & 55 & 5 & 1 \\
\hline
\end{tabular}

Table- III: Scores are obtained directly from power loom workers using NMSQ (N is Population Size).

\begin{tabular}{|l|l|l|l|l|}
\hline Sl.No & Pain/Departments & $\begin{array}{l}\text { Warping } \\
\text { N=100 }\end{array}$ & $\begin{array}{l}\text { Spinning } \\
\mathbf{N = 1 0 0}\end{array}$ & $\begin{array}{l}\text { Finishing } \\
\text { N=100 }\end{array}$ \\
\hline 1 & Lower Back & 43 & 67 & 58 \\
\hline 2 & Shoulder & 64 & 64 & 40 \\
\hline 3 & Upper Arm & 56 & 56 & 35 \\
\hline 4 & Upper Back & 50 & 50 & 39 \\
\hline 5 & Knee & 39 & 25 & 45 \\
\hline 6 & Thigh & 11 & 8 & 29 \\
\hline 7 & Ankle & 13 & 23 & 28 \\
\hline 8 & Wrist & 42 & 52 & 33 \\
\hline 9 & Neck & 52 & 42 & 35 \\
\hline 10 & Elbow & 44 & 21 & 31 \\
\hline 11 & Fingers & 15 & 17 & 27 \\
\hline
\end{tabular}


Sustainable Postural Research for Women Workers From Power-Loom Industry Solapur City, Maharashtra, India.

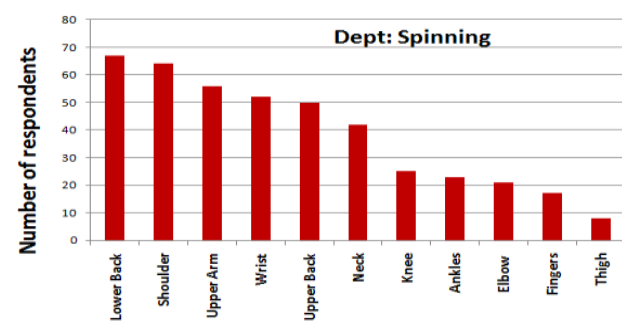

Types of Pains
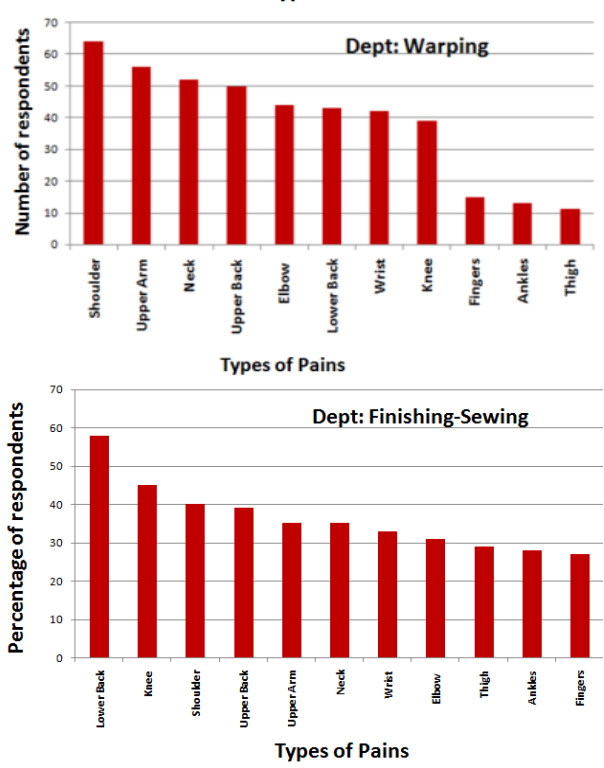

Fig.2 Pain by body parts in workers from various departments of power loom industry.

Table- IV: Obtained chart for comparing factors between RULA Wizard and NMSQ

\begin{tabular}{|l|l|l|}
\hline $\begin{array}{l}\text { Sr. } \\
\text { No }\end{array}$ & RULA & NMSQ \\
\hline 1 & Upper Arm & $\begin{array}{l}\text { Shoulder + Upper } \\
\text { Arm }\end{array}$ \\
\hline 2 & $\begin{array}{l}\text { Wrist+ Wrist } \\
\text { Twist }\end{array}$ & Wrist \\
\hline 3 & Trunk & $\begin{array}{l}\text { Upper } \\
\text { Lower Back }\end{array}$ \\
\hline 4 & Neck & Neck \\
\hline 5 & Lower Arm & Elbow \\
\hline 6 & Leg & $\begin{array}{l}\text { Thigh }+ \text { Knee + } \\
\text { Ankle }\end{array}$ \\
\hline
\end{tabular}

Table- V: Using Table 4 recomputed the RULA and NMSQ for 6 Body Regions.

\begin{tabular}{|l|l|l|l|l|l|l|}
\hline $\begin{array}{l}\text { Depts/Body } \\
\text { Parts }\end{array}$ & \multicolumn{2}{|l|}{ Warping } & \multicolumn{2}{l|}{ Spinning } & \multicolumn{2}{l|}{$\begin{array}{l}\text { Finishing- } \\
\text { Sewing }\end{array}$} \\
\hline & $\begin{array}{l}\text { RU } \\
\text { LA }\end{array}$ & $\begin{array}{l}\text { NMS } \\
\text { Q }\end{array}$ & $\begin{array}{l}\text { RU } \\
\text { LA }\end{array}$ & $\begin{array}{l}\text { NMS } \\
\text { Q }\end{array}$ & $\begin{array}{l}\text { RU } \\
\text { LA }\end{array}$ & $\begin{array}{l}\text { NMS } \\
\text { Q }\end{array}$ \\
\hline Upper Arm & 4.67 & 60 & 4 & 60 & 3 & 37.5 \\
\hline $\begin{array}{l}\text { Wrist/Wrist } \\
\text { Twist }\end{array}$ & 2.17 & 42 & 2.5 & 52 & 2 & 33 \\
\hline Trunk & 2.5 & 46.5 & 3.5 & 58.5 & 4 & 48.5 \\
\hline Neck & 3 & 52 & 3 & 42 & 3 & 35 \\
\hline Lower Arm & 2.67 & 44 & 2 & 21 & 2 & 31 \\
\hline Leg & 2 & 21 & 2 & 18.67 & 2 & 34 \\
\hline
\end{tabular}

Table- VI: Significance relation between RULA analyzed from images and NMSQ obtained from Workers.

\begin{tabular}{|c|c|c|c|c|}
\hline Methods & $\begin{array}{l}\text { Paramet } \\
\text { er }\end{array}$ & Warping & $\begin{array}{l}\text { Spinni } \\
\text { ng }\end{array}$ & Finishing \\
\hline \multirow[t]{2}{*}{ Pearson's } & $\begin{array}{l}\text { Coefficie } \\
\text { nt }\end{array}$ & 0.7952 & 0.8763 & 0.9194 \\
\hline & P Value & 0.0293 & 0.0110 & 0.00474 \\
\hline \multirow[t]{2}{*}{$\begin{array}{l}\text { Spearma } \\
\text { n's }\end{array}$} & Rho & 0.94286 & $\begin{array}{l}0.9276 \\
3\end{array}$ & 0.92582 \\
\hline & $\begin{array}{ll}\mathbf{P} & -2 \\
\text { tailed } & \end{array}$ & 0.0048 & $\begin{array}{l}0.0076 \\
7\end{array}$ & 0.00805 \\
\hline \multirow[t]{2}{*}{$\begin{array}{l}\text { Student's } \\
\text { T }\end{array}$} & T value & -7.71925 & $\begin{array}{l}- \\
5.2300 \\
8\end{array}$ & -13.12549 \\
\hline & P value & $<0.00001$ & $\begin{array}{l}0.0001 \\
92 \\
\end{array}$ & $<0.00001$ \\
\hline $\begin{array}{l}\text { Regressio } \\
\mathrm{n}\end{array}$ & $\begin{array}{l}\text { Equatio } \\
\text { n }\end{array}$ & $\begin{array}{l}13.69+10.7 \\
8 \mathrm{R}\end{array}$ & $\begin{array}{l}19.68 \mathrm{R} \\
-13.74 \\
\end{array}$ & $\begin{array}{l}7.050 \mathrm{R}+17 . \\
70\end{array}$ \\
\hline \multirow[t]{2}{*}{$\begin{array}{l}\text { Goodness } \\
\text { of Fit }\end{array}$} & $\begin{array}{l}\text { R- } \\
\text { Square } \\
\end{array}$ & 0.6323 & 0.7680 & 0.8453 \\
\hline & $\mathbf{S}_{\mathrm{y}-\mathrm{x}}$ & 8.886 & 9.877 & 2.753 \\
\hline
\end{tabular}




\section{A. Perceived Pain Condition}

Table 3 and figure 2 shows the connected leads to the share of an employee's experienced pain in several areas of the body during this occupation. Most of the examinations subjects, i.e., 67 have encountered pain in lower back whereas shoulder pain was experienced by 64 . Right wrist/hands, upper Arm and upper back 52, 56, and 50\% were the second most torture some webs website saw in the that the power-loom trade lady's operators have interaction in extended onward twisting bearing in their operating situation. The investigation obviously true that $47.23 \%$ as a traditional estimation of the themes experiencing or someone work-related contractor pain. An identical study was done by Montreuils, Laflames and Pellier on textile tufting employees handle thread cones and have reported that sixty-four.9\% had one work connected contractor pain [23]. Almost all the topic in our study had shoulder, back, and wrist pain that could was because of repetitive nature of the job and therefore the poor operating posture.Similar findings had being reported by Punnelt, Robin Keyserling in feminine garment employees [24]. This is often a big support to our study. Additionally to the share of contractor grievances this examination to boot reflected the operating posture investigation utilizing RULA.

The similar work is distributed by Tirthankar Ghosh, Banibrata Das, Somnath Gangopadhyay associated with posture adopted by the goldsmiths in their operating conditions in Republic of India [25]. Health standing in generals is found to be influenced on Neck (42\%), Thigh $(12.47 \%)$ and Ankles/Feet $(12.35 \%)$. As report within the NMQ form, past operating in squatting and standing posture was determined. The examination show additional impact of earlier period operating bearing on Ankle/Feet (23\%). It's been reported that the current work is additionally distributed beneath shoulder height associated in a painful bearing. It's important pressure more than generations of MSDs in Elbow (21\%); Neck (42\%) and higher Back (50\%) divergent tenderness from neck and shoulder was found to be very important within the pervasiveness of MSDs within the elbow. The heaviness of the body and energetic hundreds crystal rectifier to the event of pain within the knee, that 12-tone music of workers had visited the hospital. From the table 4, 5, and 6 it depicts the significance between RULA score and Nordic Musculoskeletal Questionnaires score. Statistical Analysis of Student's T and goodness of fit were performed and evaluated Pearson's and Spearman's correlation coefficients to finding significance between scores. By looking the values of correlation coefficients, there is no big difference to perform video analysis for evaluation of RULA or administer Nordic Musculoskeletal Questionnaire for finding pain in body regions. The regression equation was also found out to find NMSQ value from RULA scores.

\section{CONCLUSION}

The outcome of this study verified that the health of power-loom industry lady's operators was extremely pretentious because of inappropriate body bearings and workload. Slanting, circuitous, and over reaching these are investigation population. The results of this study disclosed

the resultant of accord running postures. These bearings need them to work during non neutral positions that increase the uneasiness and tenderness in the lower back, neck, and shoulder. The investigation tools used have been nmq and rula that can verify the condition of the employees within the vital areas that aren't ergonomically designed. The exponential kind crystallizes the influence of an individual independent variable on the dependent variable. Fast cyclic engagements and bmi also are contributory to the assembly of msds in most nine response variables. Torments in neck, lower back, hips, upper back, are significantly impacted by bmi and time of occupation.

\section{REFERENCES}

1. Adarsh Kumar (2004). Stooped and squatting posture problems in agriculture: International perspective (India) "e, in Proc. International conference on stooped \& squatting postures in the workplace, Oakland, California, USA, 29-30.

2. D. C. Metgud, Subhash Khatri, M. G. Mokashi, P. N. Saha (2008). "An ergonomic study of women workers in a woolen textile factory for identification of health related problems," Indian Journal of Occupational and Environmental Medicine" Vol.2 Issue 1, pp. 14-19.

3. Robert Norman, Richard Wells (1998). "Ergonomic Interventions for Reducing Musculoskeletal Disorders: An Overview, Related Issues and Future Directions," For the Institute for Work \& Health To the Royal Commission on Workers Compensation in British Columbia.

4. Safety requirements for the textile industry: American National Standards Institute. The Institute, New York, standard No ANSI L1. 1-1972, 1972, 16pp; Abstr. in World Textile Abstracts, App Erg 1973; 4:222-3.

5. Occupational health: the work place health and environment in sustainable development. Geneva WHO. Available at //http// www.who.in.org//.Assessed $17 / 6 / 2016$

6. Babel, Sudha and Tiwari, Meenaxi (2014). Occupational health hazards in textiles industry. Asian J. Home Sci., 9 (1): 267-271.

7. Wenzhou, Y., Ignatius, T.S.Y., Zhimin, L., Xiaorong, W., Trevor, S., Hui, L., Sabrina, W., Hong, Q., Shaohua, X., (2012). "Work-Related Injuries and Musculoskeletal Disorders among Factory Workers in a Major City of China", Accident Analysis and Prevention, 48, Pages 457-463.

8. Deros B.M., D.D.I. Daruis, I.M. Basir (2015). "A Study on Ergonomic Awareness among Workers Performing Manual Material Handling Activities". Procedia - Social and Behavioral Sciences, 195: p. 1666-1673.

9. Occupational Health and Safety Council of Ontario (OHSCO), Musculoskeletal Disorders Prevention Series, MSD Prevention Toolbox - MSD Prevention Toolbox. Ontario, 2007.

10. National Institute of Occupational Health and Safety (NIOSH). http://www.cdc.gov/niosh/. Retrieved April 27th 2008.

11. Stock S, Nicolakakis N, Raïq H, Messing K, Lippel K, Turcot A(2014). Underreporting work absences for nontraumatic work-related musculoskeletal disorders to workers' compensation: results of a 2007-2008 survey of the Québec working population. Am J Public Health; 104(3):e94-e101. 
12. Punnett L, Wegman DH(2004), “ Work-related musculoskeletal disorders: The epidemiologic evidence and the debate" Journal of Electromyography and Kinesiology 14, 13-20

13. International Ergonomics Association. 2016. What is Ergonomics? Zurich: International Ergonomics Association. Accessed 2 February 2016. http://iea.cc/whats/index.html

14. Li, G.Y., Buckle, P., 1999. Current techniques for assessing physical exposure to work related musculoskeletal risks, with emphasis on posture-based methods. Ergonomics 42, 674-695.

15. David, G.C., 2005. Ergonomic methods for assessing exposure to risk factors for work-related musculoskeletal disorders. Occup. Med-Oxford 55, 190-199.

16. Engström, T., Medbo, P., (1997). Data collection and analysis of manual work using video recording and personal computer techniques. Int. J. Ind. Ergon. 19 (4), 291-298.

17. Yen TY, Radwin RG (1995). A video-based system for acquiring biomechanical data synchronized with arbitrary events and activities. IEEE Transactions on Biomechanical Engineering.42:944-948.

18. Hernandez-Arellano JL, Serratos-Pérez JN (2014) Demographic Factors Affecting Perceived Fatigue Levels among CNC Lathe Operators. In Advances in the Ergonomics in Manufacturing: Managing the Enterprise of the Future Trzcielinski S and Karwowski W, Eds 7969-7976.

19. McAtamney, Lynn and Corlett, Nigel E (1993). RULA, a survey method for the investigation of work related upper limb disorders; Applied Ergonomics 24.

20. Dockrell, S., O'Grady, E., Bennett, K., Mullarkey, C., Mc Connell, R., Ruddy, R., \& Flannery, C., (2012). An investigation of the reliability of Rapid Upper Limb Assessment (RULA) as a method of assessment of children's computing posture. Appl. Ergon., 43 (3), 632 636.

21. Lynn McAtamney and E Nigel Corlett, 1993. RULA: a survey method for the investigation of world-related upper limb disorders. Applied Ergonomics, 24(2):91-99.

22. Kuorinka I, Josson B, Kilbom A (1987). Standardized Nordic questionnaires for the analyses of musculoskeletal symptoms. Appl Ergon;18: 233- 37

23. Montreuils S, Laflames L, Pellier C. " Profile of musculoskeletal pain suffered from textile tufting workers handling thread cones according to work, age and employment duration" Journal of Applied Ergonomics, vol. 27, pp. 85-91,1996

24. Punnett L, Robins J, Wegman D, Keyserlings W, 1985 , "Soft tissue disorders in the upper limbs of female garment workers" Scand I Work Environment Health, 11: 417-425Tirthankar Ghosh, Banibrata Das, Somnath Gangopadhyay. "Work-related Musculoskeletal Disorder: An Occupational Disorder of the Goldsmiths in India," International Journal of Community Medicine, Vol.35, Iss. 2, pp. 321-325, Apr. 2010 